\title{
Recent advances in research on hedge fund activism: Value creation and identification ${ }^{1}$
}

\author{
Alon Brav \\ Duke University \\ Wei Jiang ${ }^{2}$ \\ Columbia University \\ Hyunseob Kim \\ Cornell University
}

Forthcoming, Annual Review of Financial Economics, Vol. 7, December 2015

\begin{abstract}
Hedge fund activism has emerged as a major force of corporate governance since the 2000s. By the mid-2000s, there were between 150-200 activist hedge funds in action each year, advocating for changes in 200-300 publicly listed companies in the U.S. In this paper, we review the evolution and major characteristics of hedge fund activism, as well as the short- and long-term impact of such activities on the performance and governance of the targeted companies. Though most of the analyses are based on a comprehensive sample of over 2,000 activism events in the U.S. from 1994 to 2011, hand-collected by the authors from regulatory filings and news searches, this paper covers all major studies on the topic, including those on non-U.S. markets.
\end{abstract}

Keywords: Shareholder Activism, Corporate Governance, Productivity

\footnotetext{
${ }^{1}$ Alon Brav can be reached at phone: (919) 660-2908, email: brav@duke.edu. Wei Jiang can be reached at phone: (212) 854-9002, email:wj2006@columbia.edu. Hyunseob Kim can be reached at phone: (607) 255 8335, email: hk722@ cornell.edu.

${ }^{2}$ Corresponding author.
} 


\section{Article Table of Contents}

I. Data on Hedge Fund Activism ........................................................................... 2

II. Characteristics of Hedge Fund Activism Events...................................................... 5

III. Characteristics of Target Companies .................................................................... 7

IV. Does Hedge Fund Activism Create Value for Shareholders? ..................................... 9

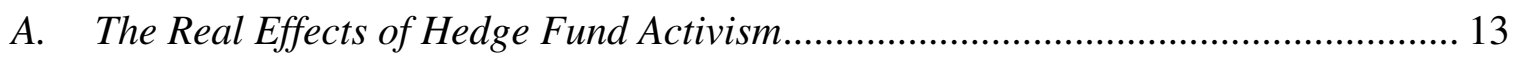

A1. Productivity before and after activism ........................................................ 14

A2. Productivity associated with capital reallocation .............................................. 15

A3. The effects of hedge fund activism on other stakeholders ................................. 16

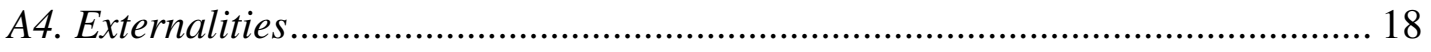

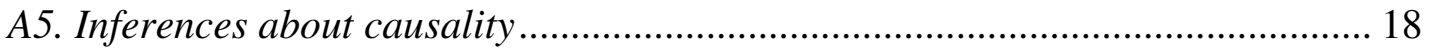

B. The Long-term effects of hedge fund activism ............................................................ 20

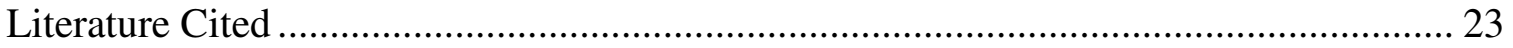

\section{Data on Hedge Fund Activism}

This section reviews the approaches researchers have taken to construct samples of hedge fund activism events. Data on activist interventions in the U.S. are generally based on Schedule 13D filings submitted to the SEC. Section 13(d) of the 1934 Securities Exchange Act requires investors who are beneficial owners of over 5\% of any class of publicly traded securities of a company, and who have an intention to influence corporate control, to disclose their ownership and intent within 10 days of crossing the 5\% threshold. The Schedule 13D filing provides the filing date and information about the identity of the filer, such as the filer's ownership and its changes, cost of purchase, and most importantly, the purpose of the investment (from Item 4 "Purpose of Transaction"). It is important to note that the SEC allows beneficial owners who have purchased shares in the ordinary course of business and do not intend to influence control to file a Schedule $13 \mathrm{G}$, which requires less information and allows the filer a longer delay in disclosure.

Brav et al. (2008) construct a comprehensive sample of activism events in the U.S. that includes interventions from both Schedule 13D filings and events with below 5\% stakes. They begin with a complete list of all Schedule 13D filers over the period 20012006, and then identify hedge fund managers based on the names and descriptions of the filer type listed in Item 2 ("Identity and Background") combined with Internet/news 
searches of the filers. Next, they gather all Schedule 13D filings and the amendments (Schedule 13D/A) available on the SEC's EDGAR system. To mitigate the concern that the Schedule 13D-based sample is biased toward smaller targets because of the large amount of capital required to acquire a stake of 5\% or more in a large-cap company, Brav et al. (2008) search Form 13Fs filed with the SEC and media outlets for events with smaller percentage stakes. Finally, Brav et al. (2008) rely on a combination of information from SEC filings and news searches from Factiva for the coding of the key aspects of events, such as the announcement date, ownership stake, stated objectives, managerial responses, and outcomes. Lastly, they exclude filings that involve risk arbitrage, distress financing, and non-regular corporations such as closed-end funds. Brav et al. (2013) and Bebchuk et al. (2014) apply the same approach, extending the sample of activist events to the period 1994-2007.

Within the U.S., most studies similarly begin with all Schedule 13D filings and then verify the identity of the filers to filter out non-hedge funds. To verify the identity of the filers, authors have used keyword searches on the Internet and other media databases (Gantchev (2013)), fund names from databases to which hedge funds may voluntarily report ( Greenwood \& Schor (2009); Boyson \& Mooradian (2010)), and/or hedge fund websites (Clifford (2008)). Most authors use multiple approaches. Additionally, while most studies begin with the universe of Schedule 13D filings, many studies then restrict the final sample to a specific setting. For example, Klein \& Zur (2009) start with all Schedule 13D filings, but restrict their sample to transactions that present an explicit activist agenda, excluding events that only present a general agenda (e.g., stock undervaluation). Similarly, Greenwood \& Schor (2009) begin with a sample of all Schedule 13D filings and definitive proxy statements filed by non-management, but restrict the sample to transactions by investment managers that have filed Form $13 \mathrm{~F}$ at some point in their history in order not to confuse corporate crossholdings with activist investment. Given that hedge fund activism is a relatively recent phenomenon, most studies use recent data from the 2000s.

Data on hedge fund activism outside of the U.S. comes, not surprisingly, from a range of sources. Becht et al. (2009) collect their sample of activism events in the U.K. using proprietary data from one hedge fund, while Mietzner \& Schweizer (2014) 
construct their sample from the disclosure of the acquisition of at least $5 \%$ of shares in public firms from the German Federal Financial Supervisory Authority. Other studies have compiled samples of activism events through extensive news/media searches (Stokman (2007); Uchida \& Xu (2008); Hamao et al. (2010)). More recently, Becht et al. (2014) gather a large sample of activism events that took place in North America, Asia, and Europe for the period 2000-2010, and they find that the Asian sample is concentrated mainly in Japan, but that there are a larger number of European countries with significant activity such as Germany, France, Italy, Netherlands and Switzerland.

The sample used for the rest of the review is based on the data collection method in Brav et al. (2008) described above, which was extended to the period 1994-2011. We also exclude target firms with non-common share codes (those that differ from 10 and 11) as identified from information from the Center for Research in Security Prices (CRSP). The final sample includes 2,624 activism events. Panel A (Panel B) in Figure 1 presents the yearly number of activism events (hedge funds) over the sample period. Two features are evident from Figure 1. First, there is a clear trend in both the number of funds and events, which is consistent with the rising success of hedge fund activism and the increase in capital committed to these funds. Second, both plots show a pro-cyclical pattern. Activism events peak in good times, whereas there is increased exit and a decline in engagements in recessions (Burkart \& Dasgupta (2014)). 


\section{Characteristics of Hedge Fund Activism Events}

Brav et al. (2008) summarize the stated objectives that the activist funds provide when they announce their intent to intervene into the following five major categories: "general undervaluation/maximize shareholder value," "capital structure," "business strategy," "sale of target company," and "governance." The objectives, except the first, are not mutually exclusive as one activist event can target multiple issues. The first category represents $59.5 \%$ of the sample and includes events in which the hedge fund believes that the company is undervalued and/or that the fund can help the manager maximize shareholder value. The second category (12.7\% of the sample) includes activism targeting firms' payout policies and capital structure. The third set of events includes activism targeting issues related to business strategy, such as operational efficiency, business restructuring, mergers and acquisitions, and growth strategies. This group represents $17.8 \%$ of all events. The fourth category, comprising $15.2 \%$ of activist events, involves activism demanding the sale of the target. In this category, hedge funds attempt either to force a sale of the target company to a third party, or, in a small minority of the cases, to acquire the company themselves. Lastly, the fifth set of events includes activism targeting corporate governance. In this category, representing $31 \%$ of the sample, hedge funds attempt to rescind takeover defenses, oust the CEO or chairman, challenge board independence and fair representation, demand more information disclosure and question potential fraud, or challenge the level or the pay-for-performance sensitivity of executive compensation. Greenwood \& Schor (2009) report a similar representation of objectives for their sample of hedge fund activism: They find that agendas related to undervaluation, capital structure, asset sales, and corporate governance represent 45.5, $11.5,18.1$, and 21.9 percent of their full sample, respectively.

Brav et al. (2008) categorize seven tactics used by hedge funds to accomplish their goals. The categorization ranges from the least to most aggressive. The first category includes events in which the hedge fund states that it intends to communicate with the board/management on a regular basis with the goal of enhancing shareholder value. Roughly $43 \%$ of the 1994-2011 sample falls into this category, and very few filings in this group publicly reveal any specific agenda by the hedge fund. The second category includes events in which the hedge fund seeks board representation without a 
proxy contest or other confrontational event. The third category includes cases where the hedge fund makes formal shareholder proposals, or publicly criticizes the management and demands change. Next, the fourth category includes events in which the hedge fund threatens to wage a proxy fight in order to gain board representation, or to sue the management for breach of duty. The fifth category includes events in which the hedge fund launches a proxy contest in order to replace the board. The remaining two groups include events in which the hedge fund sues the company in order to take control of the company (e.g., with a take-over bid).

Next, we examine the percentage ownership and the value of stakes that activist hedge funds acquire in target firms. The size of the activists' stakes in their target firms, both in dollar value (at cost) and as a percentage of outstanding shares of the target, are compiled from initial 13D filings, amendments thereof, and news sources. The median initial (maximum) percentage stake that a hedge fund takes in the target over the period 1994-2011 is $6.4(9.5) \%$, and the median dollar stake, at cost, is 13.5 (18.6) million in 2011-constant dollars. Hostile cases_-defined as events that fall into the fourth through seventh tactic categories above, or those that fall in the third category but involve a stated hostile intention (e.g., to oust the CEO)—exhibit larger ownership stakes in target firms and greater capital commitments by the hedge funds, especially at the higher percentiles of the sample.

Importantly, it is evident that these activist engagements do not generally involve controlling blocks. Even at the $95^{\text {th }}$ percentile of the sample, hedge funds hold 21.8 percent in the target companies, considerably lower than the majority requirement. These numbers are comparable across different studies. Boyson \& Mooradian (2010) document that the mean initial (maximum) percentage ownership by hedge funds in target companies is 8.8 (12.4) percent. Similarly, Greenwood \& Schor (2009) report a 9.8 percent average. It therefore appears that the activist hedge funds do not generally aim to take control of their targets. Rather, their goal is to push the target to undertake valueenhancing decisions as minority shareholders. As such, they often need support from other shareholders, especially on issues that require shareholder voting. These features distinguish the activist hedge funds from the corporate raiders in the 1980s, who sought to obtain full control to internalize all the benefits from their intervention. 
Finally, activist hedge funds' investment horizons have been an issue of contention. Critics accuse activist funds of aiming for short-term gains at the expense of long-term shareholder value. ${ }^{3}$ We measure the duration of hedge fund activists' investment in target companies from the day the market first learns of the activist stake through the "exit date" when the hedge fund significantly reduces its investment in the target company. We use the last 13D/A filing to determine when the ownership drops below the $5 \%$ disclosure threshold (i.e., the "exit date"). When such information is not available, we use the date when the outcome of sale of the target or the fund's withdrawal from the intervention is announced. Focusing on the sub-sample of the completed events where the information to determine the exit date is available, we find that the median (mean) duration from the first Schedule 13D filing to divestment is 348 (581) days, implying that the distribution of the duration is right-skewed. Furthermore, as also shown by Boyson \& Mooradian (2010), events that are initiated with hostility have a shorter investment horizon than the non-hostile events.

However, the estimates reported above generally under-estimate the unconditional duration of hedge funds' investment in the target companies because they exclude investments censored at the end of the sample period and they assume that dropping below 5\% level represents divestment. Using the annual portfolio turnover rates of the activist hedge funds (based on their quarterly holdings disclosed in 13F filings), Brav et al. (2008) report that the average holding period of a position is close to two years.

\section{Characteristics of Target Companies}

We now discuss evidence based on regression results predicting hedge funds' targeting following the specification in Brav et al. (2010). The probit regressions cover all Compustat firm-year observations from 1994 to 2011. The dependent variable is a dummy variable equal to one if the firm-year observation corresponds to a firm being targeted by a hedge fund during the year. All of the firm characteristics variables are

\footnotetext{
${ }^{3}$ See "To Battle, Armed with Shares" by Andrew Ross Sorkin, Wall Street Journal, January 4th 2006, quoting Martin Lipton, of the law firm Wachtell, Lipton, Rosen \& Katz: “...it's a terrible thing for corporate America,... I think what we're seeing is a replay of the attempt to drive American business to short-term results instead of long-term values."
} 
from various components of the WRDS database (including CRSP, Compustat, Thomson, IBES, and Risk Metrics), recorded at the year-end before the potential targeting.

The probability of activism is inversely related to the market value of equity. This result is robust and consistent with many other studies including Clifford (2008), Greenwood \& Schor (2009), Klein \& Zur (2009), Boyson \& Mooradian (2010), and Mietzner \& Schweizer (2014). Larger firms may be less appealing targets to activist funds (the median activist fund in our sample manages less than $\$ 1$ billion of assets) because of the large amount of capital a hedge fund would need to invest in order to amass a meaningful stake, which might in turn introduce an inordinate amount of idiosyncratic risk to the portfolio.

We also find that activist hedge funds behave like "value investors" attempting to identify undervalued companies where the potential for improvement is high. $q$, a proxy for firm valuation defined as (book value of debt + market value of equity)/(book value of debt + book value of equity), is inversely related to the likelihood of intervention. To the extent that activist hedge funds profit from improvement of the companies' operations and strategies, it is also important that hedge funds target companies whose stock prices have yet to reflect the potential for improvement. Target firms outside the U.S. have a similar characteristic of "value firms."

We also find that target firms tend to be less profitable than comparable firms, as measured by return on assets (ROA). Consistent with the evidence on profitability, lagged annual sales growth is also inversely related to targeting, although this result is not statistically robust. Target firms also have higher leverage, significantly lower dividend payouts, and less research and development spending than do peer firms. While the finding on R\&D is statistically weak in our sample, this result is confirmed by Boyson \& Mooradian (2010), who report that target firms have lower R\&D expenditures than matched firms at the median.

Finally, as in Brav et al. (2010), we find that targets have significantly higher institutional ownership than their peers but that analyst coverage is inversely related to intervention in a multivariate regression framework. Given that analyst coverage is positively related to the propensity of activism in a univariate regression, it is likely that the collinearity with institutional ownership and the illiquidity measure leads the sign on 
analyst coverage to flip (as both institutional ownership and analyst coverage proxy for shareholder sophistication). This is an important factor for activist hedge funds because they often rely on the understanding and support from fellow shareholders in order to implement the changes, given their minority stakes in the target firms. Using a direct trading liquidity measure, the Amihud (2002) illiquidity measure, we find that target companies exhibit higher trading liquidity than comparable firms. High liquidity makes it easier for the activists to accumulate a stake within a short period of time without incurring adverse market impact (Collin-Dufresne \& Fos (2014)).

In summary, the characteristics of target firms suggest that hedge funds tend to identify problems that are generalizable to all firms, such as changes in governance and payout policies, rather than issues that are specific to individual target firms. These targeting patterns seem sensible given that hedge funds are, in general, not experts in the specific business of the firms they invest in. Focusing on issues that are generalizable to other potential target firms helps to lower the marginal cost of launching activism on a new company (Black (1990)). Another reason to avoid targeting an idiosyncratic firm issue is offered by Kahn \& Winton (1998). Their theory predicts that investors are more likely to intervene in well-understood firms or industries so that the market can appreciate the effects of intervention.

\section{Does Hedge Fund Activism Create Value for Shareholders?}

We now ask whether hedge fund activism generates value for shareholders. We address this question by examining both short-run stock returns around the announcement of activism as well as subsequent long-run returns.

Figure 2 plots the average buy-and-hold return, in excess of the buy-and-hold return on the CRSP value weight index, from 20 days prior to the event date to 20 days afterwards for all events from 1994 to 2011. The event date is defined as the Schedule 13D filing date if available, or the first announcement of targeting if the hedge fund ownership stake is lower than 5 percent. The average abnormal return for the entire event period is about $5 \%$. Importantly, half of this abnormal return takes place in the few days leading up to filing. 
The magnitude of the announcement-window abnormal returns is comparable with those in other studies on U.S. activism events. Klein \& Zur (2009) report a similar 7.2 percent for the $[-30,+30]$ window. Clifford (2008), Greenwood \& Schor (2009), and Boyson \& Mooradian (2010) document significantly positive average abnormal announcement-day returns ranging from 3.4 to 8.1 percent for various event windows.

The stock market's reaction to the disclosure of activist funds' engagement in a target outside the U.S. is broadly consistent with the U.S. experience. Becht, Franks, Mayer, and Rossi (2009) report that the mean abnormal return over the $[-5,+5]$ window around the announcement of activism outcomes is 3.94 percent in the U.K. Similarly, Becht et al. (2010) and Stokman (2008) document that average cumulative abnormal returns around the $[-25,+25]$ announcement-day window ranges from about 6-12 percent for activism events in Europe. For Japan, Uchida \& Xu (2008) document an average excess return of 5.6 percent for the $[-2,+2]$ window around the announcement of activist events. Combined evidence suggests that investors perceive hedge fund activism as value-enhancing for shareholders.

Figure 2 also shows the average abnormal trading volume over the event window (dashed line). The abnormal volume is defined as the share turnover rate over the "normal" turnover rate measured over the $[-100,-40]$ window preceding the event date. The spike in abnormal trading volume does not occur on the event day but rather during the ten-day period before the announcement. The ten day lead seems to be consistent with the fact that investors are required to file Schedule 13D no later than ten days after the transaction causing them to exceed the 5\% threshold. Therefore, it is possible that the filing fund may be engaging in additional buying prior to the announcement of activism. Alternatively, the abnormal volume in the days preceding the filing date may be consistent with "wolf pack" investing, in which several hedge funds, who do not formally coordinate, buy into the target firm or with "tipping," where the lead hedge fund reveals its intention to a small number of investors before the public filing.

Further evidence on the time-series properties of the short-run average abnormal return is given in Figure 3. The yearly average abnormal return during the $[-20,+20]$ window exhibits an interesting counter-cyclical pattern. The average abnormal event-day return is almost $14 \%$ on average in 2001 and $8 \%$ in 2009, but is less than 2 percent in 
2007-2008. This decline may be driven by competition just like any other investment strategy: hedge funds' activist "arbitrage" strategy intensified over the years, leading to the entry of more players into the field, which in turn reduced the equilibrium returns to activism.

Various studies explore the cross-sectional heterogeneity in market perceptions regarding the expected value generated by activism. Greenwood and Schor (2009) report that abnormal returns are the highest for events related to asset sales and block mergers of the target firm. Brav et al. (2010) find that activism announcements in which the activist's intent is to sell the target generates the highest abnormal return, with an average of 8.54 percent. Becht et al. (2010) document a similar difference in average abnormal returns between acquired and non-acquired targets ( 8.1 vs. 5.2 percent) for activism events in Europe. On the other hand, the initial returns related to governance-related hedge fund activism are mixed. While Boyson \& Mooradian (2010) report that governance-related hedge fund activism is associated with the most favorable stock market reaction, Becht et al. (2010) find that the abnormal returns generated by governance issues are not statistically distinguishable from zero.

It is possible that the positive abnormal returns document in these short event windows are temporary and reflect a trading friction rather than information about prospective value changes. If so, we should observe negative abnormal returns shortly after the event. This is not to be the case in our data-extending Figure 2 shows that abnormal returns are not negative, but are instead roughly zero. These results are comparable to those in Clifford (2008), who also runs calendar-time portfolio regressions for the target firms in his sample. For windows of $[0,+12],[0,+24]$, and $[0,+36]$ (in months), he finds that the average three- and four-factor alphas range from 1.0 to 1.9 percent per month and that they are statistically significant. More formal return analyses based on the five years following intervention are discussed in the next section and corroborate the conclusion that abnormal prices do not decline post-event. This evidence refutes a market over-reaction hypothesis and supports the hypothesis that hedge fund activism creates value for shareholders. Yet, evidence on increased shareholder wealth 
may not be sufficient to demonstrate that hedge fund activism creates real, long-term value for the target firm and its stakeholders. This is the topic discussed in the next section.

\section{The Real and Long-term Effects of Hedge Fund Activism}

Though there has been little controversy over the positive short-term stock market reaction, there has been significant recent debate over whether the effects of shareholder activism are "real" — that is, whether activists have a long-term effect on firm "fundamentals" that lasts beyond the short-term market reaction or whether activist interventions are mere "financial engineering." Most critics of hedge fund activism have argued that activists narrowly focus on short-term financial performance, and that such "short-termism," as well as a focus on financial metrics, is detrimental to the long-term value of the target companies. This concern over short-termism has been repeated by academics (Bratton \& Wachter, (2010), Fox \& Lorsch (2012), George \& Lorsch (2014)), members of the government (Donaldson (2006), Strine (2010; 2014)), and practitioners (Wachtell, Lipton, Rosen \& Katz (2013) Memorandum ${ }^{4}$ ).

These opponents of hedge fund activism argue that although operating performance and abnormal stock returns in the year following intervention are positive, the initial metrics reflect unsustainable changes that have been achieved through financial engineering such as shareholder distributions or increased leverage, and will not translate into long-term improvement once a proper benchmark is set. They frequently argue that gains to activists reflect wealth-transfers from other firm stakeholders rather than evidence of long-term value creation. For example, they argue that activists benefit at the expense of long-term shareholders through "pump and dump" schemes, in which the activist sells the shares after earning a short-term profit. The critics can also point to studies such as Klein \& Zur (2011), which showed that bondholders experience negative

\footnotetext{
${ }^{4}$ Wachtell, Lipton, Rosen \& Katz Memorandum, Bite the Apple; Poison the Apple; Paralyze the Company; Wreck the Economy, The Harvard Law School Forum on Corporate Governance and Financial Regulation. Available at: http://blogs.law.harvard.edu/corpgov/2013/02/26/bite-the-apple-poison-the-apple-paralyze-the-companywreck-the-economy/.
} 
abnormal returns following activist interventions, to argue that the purported gains from activism reflect wealth transfers rather than overall net gains.

In this section, we present comprehensive empirical evidence to directly address the concerns regarding the "real" and "long-term" effects of hedge fund activism.

\section{A. The Real Effects of Hedge Fund Activism}

The most "real" part of the economy is probably the production process. About one-third of the companies targeted by hedge fund activists are manufacturing firms whose activities at the plant level are covered by the U.S. Census Bureau's Annual Surveys of Manufacturers (ASM) and the Census of Manufacturers (CMF) ${ }^{5}$ (henceforth, the "Census data") (this proportion is comparable to the representation of manufacturing firms in the universe of publicly listed companies). The Census data provide crucial elements of the production process, such as the plant assets, number of employees, annual payroll, capital and materials used, and ownership status. Matching the Census data with a sample of hedge fund activism events from 1994 to 2007, Brav et al. (2013) find that plant productivity following activist intervention increases relative to the time of intervention, suggesting that activists make real changes to the target firms' fundamental values. Because hedge fund activists may increase firm productivity by either improving the efficiency of assets in place or by reallocating capital, the authors further examine both channels and find that activists increase firm productivity through both channels.

The results in Brav et al. (2013) have several important implications. First, activists target firms with plants that are at equal or greater levels of productivity than a set of control plants. This result is consistent with the finding in Brav et al. (2008) that hedge funds generally target mature firms that have relatively strong business fundamentals, but that are facing difficulty due to mismanagement or other governance problems. Second, plant productivity increases following intervention. The increase is due both to an increase in the efficiency of assets in place and to reallocation of underperforming assets. Third, although plant productivity increases, the employees experience a reduction in work hours and stagnation in wages.

\footnotetext{
${ }^{5}$ The Longitudinal Business Database (LBD), another establishment-level dataset maintained by the Census Bureau, covers all economic sectors in the U.S. providing relatively limited information on the operation of establishments. See Brav et al. (2013) for more information on the LBD.
} 


\section{A1. Productivity before and after activism}

When Brav et al. (2013) examine the productivity of assets in place they find that productivity declines in the years prior to intervention, but then rebounds steadily afterwards. Plant productivity, measured as total factor productivity (“TFP”), is defined as the difference between the actual and predicted output given the inputs, and is calculated as the residual from a log-linear Cobb-Douglas production function run at the industry-year level (e.g., Lichtenberg \& Siegel (1990); Lichtenberg (1992); Schoar (2002); Bertrand \& Mullainathan (2003); and Giroud (2011)). The TFP measure can thus be interpreted as the relative productivity rank for each plant within its specific industry in that year. Regressing TFP on seven key independent variables corresponding to the three years before the event, the year of the event, and the three years following the activism event, the authors show that firm productivity in the years surrounding intervention appears to follow a V-shaped pattern in which the year of intervention is the base year in the "V." Importantly, the increase in firm productivity in the third year following intervention is statistically significant and economically meaningful. On average, TFP at targeted plants increases by $7.7-10.8 \%$ of the standard deviation from the year of intervention to three years afterwards.

The increase in plant productivity is particularly prevalent in industries with low concentration (Brav et al. (2011)). Prior literature on industry concentration and corporate governance has suggested these two forces may work as substitutes (Bauer et al. (2010); Giroud \& Mueller (2010; 2011)). However, the effect of market concentration is unclear in this setting because hedge fund activism is distinct from the prior forms of governance studied. Unlike takeovers, activism is not control-driven. Additionally, unlike internal forms of governance, activism is market-based. The authors thus address the question empirically and show that there is a greater increase in TFP in industries with low concentration, suggesting that market competition and outside shareholder monitoring are potential complements. The result is economically meaningful: the magnitude of a change in productivity from year $\mathrm{t}$ to year $\mathrm{t}+3$ is 2.8 times larger in the least concentrated industries compared to the most concentrated ones. 


\section{A2. Productivity associated with capital reallocation}

Given the evidence that productivity increases following the intervention, an equally important question is whether such improvements are accomplished through improvements in the efficiency of assets in place, capital reallocation, or both. Brav et al. (2008) and Greenwood \& Schor (2009) show that initial stock returns are greatest for those activism events in which the stated goal is to push for the sale of the target. However, these early studies left three unanswered questions. First, data at the firm level provides limited inference on the separation between assets in place and redeployment. Second, operating performance based on accounting data, such as ROA, cannot capture real changes at the production-unit level. Third, about $25.5 \%$ of the firms targeted by hedge funds activists drop out of Compustat within two years (this is almost double the average attrition rate for firms in Compustat). Hence, firm-level analysis may suffer from an attrition bias. The plant level analysis that can be conducted using the Census data has provided significant progress on these issues.

Plant-level asset redeployment reveals key aspects of activists' impact that are hard to qualify and quantify at the firm level. Brav et al. (2013) show that underperforming plants are more likely to be sold following hedge fund intervention compared with plants of similar attributes. While roughly $23 \%$ of the plants of targeted companies were sold during the three years following intervention, the same sale rate for plants at non-targeted companies was $13 \%$. Notably, the high rate of plant sales is even more pronounced when the plant belongs to an industry with low concentration, suggesting the role of asset redeployability (Williamson (1988)) and the number of potential buyers in facilitating physical capital reallocation.

The divestiture of negative NPV assets, on its own, could enhance value for the shareholders, but it is not clear whether it increases overall efficiency across the economy. If the poorly performing plant experiences an increase in productivity under new ownership, this strengthens the argument that asset redeployment associated with hedge fund activism creates value. Further analysis shows that plants sold after intervention exhibit the familiar $\mathrm{V}$-shaped pattern in which productivity decreases during the two years before the sale, but then increases after the sale. Moreover, the increase in productivity for plant sales following hedge fund intervention is roughly six times greater 
than the increase in productivity for plant sales that were not associated with hedge fund intervention.

\section{A3. The effects of hedge fund activism on other stakeholders}

Some of those who oppose hedge fund activism express the concern that the shareholder gain could be a result of wealth transfer from other stakeholders rather than value creation. The literature so far has analyzed the effects on the other two most important groups of stakeholders: creditors and employees.

\section{(i) Creditors}

The effect of hedge fund intervention on creditors based on the existent studies is mixed with a close-to-neutral average impact. Moreover, the outcome appears to be heterogeneous largely depending on the objectives of activists. Using a sample of public bonds from 1994-2006, Klein \& Zur (2011) find that there are, on average, abnormal bond returns of $-3.9 \%$ surrounding the initial Form 13D filing, and that the initial negative returns are followed by an additional $-4.5 \%$ decrease over the following year.

Several other analyses have investigated the cross-sectional differences noted in Klein \& Zur (2011) using both public and private debt, and have reached varying conclusions regarding the net effect on all creditors. For example, Aslan \& Maraachlian (2009), using a sample of public bonds from 1996-2008, find that bondholders experience positive abnormal returns of roughly $2 \%$ upon the initial Schedule 13D filing, but negative abnormal returns of $3-5 \%$ in the first year following intervention. While bondholders with weak covenant protections and those involved in capital structure driven events experienced losses, bondholders enjoyed positive returns from activism relating to monitoring (e.g., corporate governance).

Using data on bank loans, Sunder et al. (2013) and Li \& Xu (2010) both find that spreads increase following hedge fund interventions in which the activist intends to make capital structure changes to the target firm (e.g., increased shareholder payouts). However, both analyses also find that hedge fund activism may decrease the cost of debt when the activist serves a monitoring function. Both papers report that there are changes in contract terms such as the number and type of covenants following intervention. Overall, the 
results show that there are changes in the target's credit risk, but that the changes are not necessarily either positive or negative. Based on a sample of firms in Chapter 11, Jiang et al. (2012) find that hedge fund intervention balances the power of senior creditors relative to management, and tends to be associated with better outcomes for junior creditors, in the form of higher probability of emergence and better recovery.

\section{(ii) Employees}

As expected, activists are not kind to senior managers such as CEOs. Brav et al. (2008) and Fos (2014) show that CEO turnover doubles and compensation is moderated and more sensitive to performance after activist intervention. While most observers tend to view these changes as signs of better governance, a related concern might arise as to whether hedge fund activism might also negatively impact employees below the executive rank.

Brav et al. (2013) analyze the changes in wages and work hours for factory workers and staff using the plant-level data. They show that the number of workers and the hours per worker decrease following intervention, but that output per hour (a measure of labor productivity) increases. The change in wages is not itself statistically significant, but the magnitude of the decrease in the number of total labor hours is economically meaningful: there is a $10 \%$ decrease in total labor hours from the year of intervention to three years later. The intervention reduces a wage level that is significantly above peers to a level that is at par with the industry peers. The increase in productivity per hour is also meaningful as there is a $7.3 \%$ increase in labor productivity in the three years following intervention. This result is consistent with the argument made by Shleifer and Vishny (1986) and Pagano \& Volpin (2005) that tightened monitoring on the target's management is associated with improved labor efficiency and more scrutiny over generous wages. Moreover, the increase in the sensitivity of executive compensation to performance could give mangers stronger incentives to monitor employees and improve their efficiency. Relatedly, Popadak (2014) shows that hedge fund activism reduces the "culture" orientation of the firm, where culture includes customer-focus, employee integrity, and collaboration. 


\section{A4. Externalities}

More recently, several papers examine how the "threat" of activism has a spillover effect that disciplines managers at non-target companies. Fos (2014) studies proxy contests and demonstrates that the mere threat, as measured by the probability of being targeted, accomplishes similar outcomes to actual proxy contests because firms under the "threat" take pre-emptive actions such as increased payouts and leverage, reduction in investment, and heightened CEO turnover and scrutiny over CEO pay.

Gantchev et al. (2014) conduct a similar analysis in a more general setting of hedge fund activism. The authors note that it is difficult for managers to protect themselves from activists using traditional tools such as poison pills, and managers instead try to defend their companies from activists by pre-emptively addressing their perceived vulnerabilities. As the threat of activism increases, companies sharing the same fundamentals as previously targeted companies respond by improving asset utilization, reducing capital expenditures, and increasing both shareholder payouts and leverage. Zhu (2013) finds a similar effect, with additional evidence on operating performance improvement.

In sum, the threat of activism produces positive externalities at non-target firms. This is consistent with anecdotal evidence from practitioners that managers attempt to self-correct when they are concerned that they will become a target.

\section{A5. Inferences about causality}

Although the combined results from the literature are consistent with activists improving performance, these results do not prove a causal relationship. In fact, the observed statistical relations are most plausibly a combination of the effects of stock picking and effort exertion by the activists. Hedge funds are sophisticated investors who could potentially profit from picking companies with improving prospects even if they remain passive stakeholders, and at the same time hedge funds are likely to choose those battles in which they can more effectively influence the outcome in their favor.

For this reason, a standard average treatment effect, i.e., the improvement a hedge activist could bring about if it were randomly assigned to a company, is likely to be limited; moreover, the identification of such an effect is also of limited value for policy 
implications. A more interesting question would be as follows: conditional on hedge funds' selection of targets, would the same outcome prevail if it weren't for hedge funds' effort (that is, if the funds remain merely as passive investors)?

The cumulative research to date suggests there is a positive effect of hedge fund activism beyond stock picking. Certain changes (notably an almost doubling of CEO turnover) are necessarily outcomes of confrontation, which are unlikely to have occurred but for the persistence of the activists. Moreover, undiversified long-term positions together with costly engagements, including proxy contests or public campaigns (Gantchev (2013)), cannot be justified by pure stock picking. In addition, openly hostile activism events generate higher announcement returns than non-confrontational events. And revelation of activist stakes, disclosed on a Schedule 13D, generates higher returns than the revelation of large passive stakes, disclosed with a longer delay on Schedule 13G (see Klein \& Zur (2009), Clifford (2008)). Finally, Becht et al.'s (2014) multi-country evidence that abnormal returns during the entire activist engagement period are significantly higher for engagements with specific objectives compared to those without cannot be reconciled with stock picking alone.

Brav et al. (2013) conducted additional tests to directly analyze three specific alternate hypotheses. First, they address the possibility that management would have instituted the aforementioned changes absent hedge fund intervention. The authors refute this hypothesis by analyzing only a subsample of confrontational events in which management displayed public resistance to the activist's agenda, and discovering the same pattern for TFP following activist events. Second, they address the possibility that activists are sophisticated stock pickers who select firms that are best positioned to benefit from an industry shock. For this analysis, they use a subsample of firms that have plants in both the primary industry to which the firm belongs and in non-primary industries, and they find that improvements in plants in non-primary industries are just as strong as improvements in the primary industry. Finally, they address the possibility that activists are able to select stocks that are poised for improvement, and that their results are driven by activists' stock picking ability rather than intervention. For this analysis, they use a subsample of firms that switched from a passive stance to an active stance and thus switched from the $13 \mathrm{G}$ filing required for passive investors to the 13D filing 
required for activist investors (or required when a formerly passive investors decides that it may now become an active investor). The results indicate that the performance of plants increases after a passive investor becomes active.

The literature examining the spillover effects of activism, reviewed earlier, also needs to address the challenge that the threat of an activist intervention may be correlated with unobserved industry or firm characteristics that are also correlated with outcomes. Fos (2014) uses the 1992 proxy reform as an exogenous shock to the cost of launching proxy contests, and then analyzes the differential effect of stock liquidity. Liquid firms have been shown to have a higher likelihood of being targeted than non-liquid firms because stock market liquidity facilitates the rapid position accumulation by activists (Norli et al. (2014)). Gantchev et al. (2014) use contemporaneous institutional trading in stocks outside of the potential target's industry as an instrument for the likelihood of an activist threat. The intuition behind this instrument is that institutional trading is unrelated to firm fundamentals, but can cause a temporary market misevaluation due to fund flows that function as a random shock causing some marginal firms to become attractive target candidates. Aslan and Kumar (2014) uncover a negative impact of hedge fund targeting on industry peers especially when product markets are more competitive, using tariffs as instruments.

\section{B. The Long-term effects of hedge fund activism}

While the previous section demonstrates that hedge fund intervention brought about changes beyond financial engineering or nominal jawboning, this section shows that the real changes last beyond the intervention years. The review is mostly based on the study by Bebchuk et al. (2014). Due to the fact that hedge fund activism is a relatively new phenomenon that became common place only in the 2000s (see Figure 1), data availability limits the duration of the event window - with five years chosen as the event window for the long term ex post analyses.

\section{B1. Operating performance and stock returns}


Bebchuk et al. (2014) present robust evidence that the positive effects on operating performance last at least five years post intervention, and that the short-term stock price jump does not reverse in the longer term.

Bebchuk et al. (2014) show that activism target firms underperform their peers at the time of intervention, but that performance increases steadily in the following five years. This finding is based on both simple comparisons with industry peers and a series of regressions using ROA and Tobin's Q to reflect operating performance and independent dummy variables reflecting each of the three years prior to intervention, the year of intervention, and each of the five years following intervention. Using simple industry-adjusted comparisons, the authors show that ROA (Tobin's Q) in the year of intervention is $-0.025(-0.467)$, but that it increases steadily to $-0.006(-0.097)$ five years later where the change is significant. The results in their regressions reveal a similar and stronger pattern. ROA and Tobin's Q are negative in the year of intervention for all four specifications, but are higher than the base year in each year following intervention in all specifications. This analysis directly contradicts criticism that activists are so myopically focused on short-term results that they destroy long-term value. Moreover, this result is consistent with the finding of Brav et al. (2013) that plant-level productivity keeps improving significantly for three years after the year of intervention.

Bebchuk et al. (2014) also examine long-term abnormal stock returns for target firms. Opponents of hedge fund activism argue that the initial spike in stock returns discussed in Section IV is a result of temporary over-reaction that is later reversed (Wachtell, Lipton, Rosen, \& Katz (2013)). Bebchuk et al. (2014) test whether this reversal occurs using three alternate calculations of abnormal returns. First, the authors test whether target companies experience negative abnormal returns in the five years following intervention by computing firm-level returns based on the CAPM and the Fama-French four factor model (Fama \& French (1993), Carhart (1997)) using individual firm-level regressions. Second, they create a matched set of firms based on size and book-to-market and test whether target firms experienced lower average abnormal buy and hold returns than the matched set. Finally, they test whether a calendar-time portfolio that purchased a position in each target company following the $13 \mathrm{D}$ announcement window experienced abnormal returns. 
In all instances, the authors find no evidence that target companies underperform given their risk characteristics. Beginning with the firm-level regressions, the alphas are negative and economically meaningful for the three years prior to intervention, but positive and economically meaningful for the three- and five-year periods following the intervention. The mean monthly alpha for a three-year holding period based on the CAPM (Fama-French model) is 0.50 (0.32), and the mean alpha for a five-year holding period based on the CAPM (Fama-French model) is 0.65 (0.40), excluding the announcement window returns. Using the buy and hold returns, the results indicate that the abnormal returns for both the three- and five-year periods following intervention are positive, but not statistically different from zero. Finally, the alphas for the three and five year periods following intervention are positive and economically meaningful in three of the four specifications, and negative but economically insignificant in the final estimate. Overall, the results do not provide any evidence of long-term underperformance, and there is no evidence to suggest that the initial spike in stock price reverses.

\section{A. The most likely "short-termist" schemes}

Bebchuk et al. (2014) examine the three most likely "short-termist" schemes in isolation so as to better detect any evidence of post-intervention underperformance. The schemes are the following: the "pump and dump" scheme, the "asset stripping" criticism, and "adversarial" interventions.

According to the "pump and dump" argument, hedge funds enjoy sizable abnormal returns while holding the stock, but then sell the stock after subjecting the company through various acts of financial engineering such as leveraged recapitalizations. This scheme allows the activist to benefit at the expense of other shareholders, who are left with tarnished assets and negative abnormal returns. To test whether firm returns do in fact decrease after the activist sells her shares, the authors focus on the stock returns in the three years following the filing of an amendment to the original Schedule 13D indicating that the activist's holdings have fallen below the five percent threshold. They calculate abnormal returns using individual firm regressions, a comparison of buy and hold returns, and long-term portfolio analysis. In all instances, they find no evidence suggesting that the target companies underperform following the activists' departure- 
abnormal returns are either significantly positive or, at worst, not significantly different from zero.

Critics of hedge fund activism frequently note that some activists reduce firm resources by stripping the firm of assets via cash payouts and asset sales, and they point to this tactic as particularly detrimental because they claim the target firm is saddled with increased risk and decreased flexibility following the intervention (Wachtell, Lipton, Rosen, \& Katz (2013)). Bebchuk et al. (2014) constructed a subset of interventions in which there were substantial reductions in capital investments, increases in leverage, or increases in payouts to shareholders. The analysis of long-term performance for only this subset, about $19 \%$ of the sample, shows a similar pattern with the full sample-operating performance is greater in each of the five years following the intervention than the year of intervention, and the difference between performance in the base year and in years three through five is generally statistically significant. These results suggest that activists' actions reduce agency conflicts by moving the company closer to an optimal level of cash holdings and investment.

Adversarial interventions are also frequently cited as detrimental to the targets by opponents of activism who argue that managers are distracted by the activist and unable to run the company. Bebchuk et al. (2014) consider the intervention to be adversarial when any 13D filing indicates that a proxy contest, lawsuit, or confrontational public campaign might be necessary to fulfill the activists' intentions. They find that roughly $22 \%$ of interventions can be classified as adversarial. As in the previous subset analysis, operating performance for each of the five years following the intervention is higher than in the year of intervention, and the increase from the base year to years three through five is generally significant. Overall, contrary to arguments advanced by critics of activism, the authors show that there is no evidence of negative long-term performance following adversarial interventions.

\section{Literature Cited}

1. Amihud Y. 2002. Illiquidity and stock returns: Cross-section and time-series effects. J. Financial Markets. 5:31-56. 
2. Aslan H, Maraachlian, H. 2009. Wealth effects of hedge fund activism. Work. Pap., Geogian State Univ .

3. Aslan H, Kumar P. 2014. The product market effects of hedge fund activism. Work. Pap., Univ. of Houston.

4. Bauer R, Braun R, Viehs M. 2010. Industry competition, ownership structure and shareholder activism. Work. Pap., Maastricht Univ./Oxford Univ. Smith Sch. of Enterprise and the Environment.

5. Bebchuk LA, Brav A, Jiang W. 2014. The long-term effects of hedge fund activism. Columbia Law Review. Forthcoming.

6. Becht M, Franks JR, Mayer C, Rossi S. 2009. Returns to shareholder activism: Evidence from a clinical study of the Hermes UK focus fund. Rev. Financ. Stud. 22(8): 3093-129.

7. Becht M, Franks JR, Grant J. 2010. Hedge fund activism in Europe. Work. Pap., Université Libre de Bruxelles/London Bus. Sch./Univ. of Cambridge.

8. Becht M, Franks J, Grant J, Wagner H. 2014. The returns to hedge fund activism: An international study. Work. Pap., Université Libre de Bruxelles/London Bus. Sch./CM-CIC Securities/ Bocconi Univ.

9. Bertrand M, Mullainathan S. 2003. Enjoying the quiet life? Corporate governance and managerial preferences. J.. Political Economy. 111:1043-75.

10. Black B. 1990. Shareholder passivity reexamined. Michigan Law Review. 89:520-608.

11. Boyson NM, Mooradian RM. 2010. Intense hedge fund activists. Work. Pap., Northeastern Univ.

12. Bratton WW, Wachter ML. 2010. The case against shareholder empowerment. Univ. of Pennsylvania Law Review. 158:653-728.

13. Brav A, Jiang W, Partnoy F, Thomas R. 2008. Hedge fund activism, corporate governance, and firm performance. J. Finance. 63(4), 1729-75.

14. Brav A, Jiang W, Kim H. 2010. Hedge fund activism: A review. Foundations and Trends in Finance. 4(3):1-66.

15. Brav A, Jiang W, Kim H. 2011. The real effects of hedge fund activism: Productivity, risk, and product market competition. NBER Work. Pap. 17517. 
16. Brav A, Jiang W, Kim H. 2013. The real effects of hedge fund activism: Productivity, asset allocation, and industry concentration. Work. Pap., Duke Univ./Columbia Univ./Cornell Univ.

17. Burkart M, Dasgupta A. 2014. Activist funds, leverage, and procyclicality. Work. Pap., Stockholm Sch. of Economics/ London Sch. of Economics.

18. Carhart MM. 1997. On persistence in mutual fund performance. J. Finance. 52(1): $57-82$.

19. Clifford CP. 2008. Value creation or destruction? Hedge funds as shareholder activists. J. Corp. Finance. 14: 323-36.

20. Collin-Dufresne P, Fos V. 2014. Do prices reveal the presence of informed trading? J. Finance. Forthcoming.

21. Donaldson W. 2006. CFA Center for Finance Integrity \& Business Roundtable Institute for Corporate Ethics. Breaking the Short-Term Cycle: Discussion and Recommendations on How Corporate Leaders, Asset Managers, Investors and Analysts Can Refocus on Long-Term Value http://www.corporateethics.org/pdf/Short-termism_Report.pdf

22. Fama E, French KR. 1993. Common risk factors in the returns on stocks and bonds. J. Financ. Econ. 33(1):3-56.

23. Fos V. 2014. The disciplinary effects of proxy contests. Work. Pap., Univ. of Illinois at Urbana-Champaign.

24. Fox J, Lorsch JW. 2012. The big idea-What good are shareholders? Harvard Bus. Rev. July-August.

25. Gantchev N. 2013. The costs of shareholder activism: Evidence from a sequential decision model. J. Financ. Econ. 107(3):610-31.

26. Gantchev N, Gredil O, Jotikasthira C. 2014. Governance under the gun: Spillover effects of hedge fund activism. Work. Pap., Univ. of North Carolina at Chapel Hill.

27. George B, Lorsch JW. 2014. How to outsmart activist investors. Harvard Bus. Rev. May.

28. Giroud X, Mueller H. 2010. Does corporate governance matter in competitive industries. J. Financ. Econ. 95:312-31. 
29. Giroud X. 2011. Proximity and investment: Evidence from plant-level data . Q. J. Econ. Forthcoming.

30. Giroud X, Mueller H. 2011. Corporate governance, product market competition, and equity prices. J. Finance. 65:563-660.

31. Greenwood R, Schor M. 2009. Investor activism and takeovers. J. Financ. Econ. 92:362-75.

32. Hamao K, Kutsuna K, Matos PP. 2010. U.S.-style investor activism in Japan: The first ten years. Work. Pap., Univ. of Southern California/ Kobe Univ./Univ. of Virginia.

33. Jiang W, Li K, Wang W. 2012. Hedge funds and Chapter 11, J. Finance. 67(2):513-60.

34. Kahn C, Winton A. 1998. Ownership structure, speculation, and shareholder intervention. J. Finance. 53(1): 99-129.

35. Klein A, Zur E. 2009. Entrepreneurial shareholder activism: Hedge funds and other private investors. J. Finance. 64(1):187-229.

36. Klein A, Zur E. 2011. The impact of hedge fund activism on the target firm's existing bondholders. Rev. Financ. Stud. 24(5):1735-71.

37. Lichtenberg FR, Siegel D. 1990. The effects of leveraged buyouts on productivity and related aspects of firm behavior. J. Financ. Econ. 27:165-94.

38. Lichtenberg FR. 1992. Corporate Takeovers and Productivity. Cambridge, MA: MIT Press

39. Mietzner M, Schewizer D. 2014. Hedge funds versus private equity funds as shareholder activists in Germany-differences in value creation. J. Financ. Econ. 38:181-208.

40. Norli O, Ostergaard C, Schindele I. 2014. Liquidity and shareholder activism. Rev. Financ. Stud. Forthcoming.

41. Pagano M, Volpin PF. 2005. Managers, workers, and corporate control. $J$. Finance. 60:841-68.

42. Popadak J. 2014. A corporate culture channel: How increased shareholder governance reduces firm value. Work. Pap., Duke Univ. 
43. Schoar A. 2002. The effect of diversification on firm productivity, J. Finance 62(6):2379-403.

44. Shleifer A, Vishny RW. 1986. Large shareholders and corporate control. $J$. Political Econ. 94(3):461-88.

45. Sorkin A.2013. 'Shareholder Democracy' Can Mask Abuses. New York Times. Feb. 25, p. B1.

46. Stokman NWA. 2007. Influences of hedge fund activism on the medium term target firm value. Work. Pap., Erasmus Univ. Rotterdam.Strine, LE Jr. 2010. One fundamental corporate governance question we face: Can corporations be managed for the long term unless their powerful electorates also act and think long term? The Business Lawyer. 66:1-32.

47. Strine, LE Jr. 2014. Can we do better by ordinary investors? A pragmatic reaction to the dueling ideological mythologists of corporate law. Columbia Law Review. 114:449-502.

48. Sunder J, Sunder SV, Wongsunwai W. 2014. Debtholder responses to shareholder activism: Evidence from hedge fund interventions. Rev. Financ. Stud. Forthcoming.

49. Uchida K, Xu P. 2008. U.S. barbarians at the Japan gate: Cross border hedge fund activism. Work. Pap., Univ. of Kitakyushu/ Hosei Univ.

50. Wachtell, Lipton, Rosen \& Katz Memorandum. 2013. Bite the Apple; Poison the Apple; Paralyze the Company; Wreck the Economy. Reprod. The Harvard Law School Forum on Corporate Governance and Financial Regulation. Feb. 26. Williamson OE. 1988. Corporate finance and corporate governance, J. Finance. 43:567-91.

51. Xu J, Li Y. 2010. Hedge fund activism and bank loan contracting. Work. Pap., Purdue Univ./Arizona State Univ.

52. Zhu H. 2013. The preventive effect of hedge fund activism. Work. Pap., Duke Univ. 
Figure 1: Number of Funds and Activism Events by Year: 1994-2011
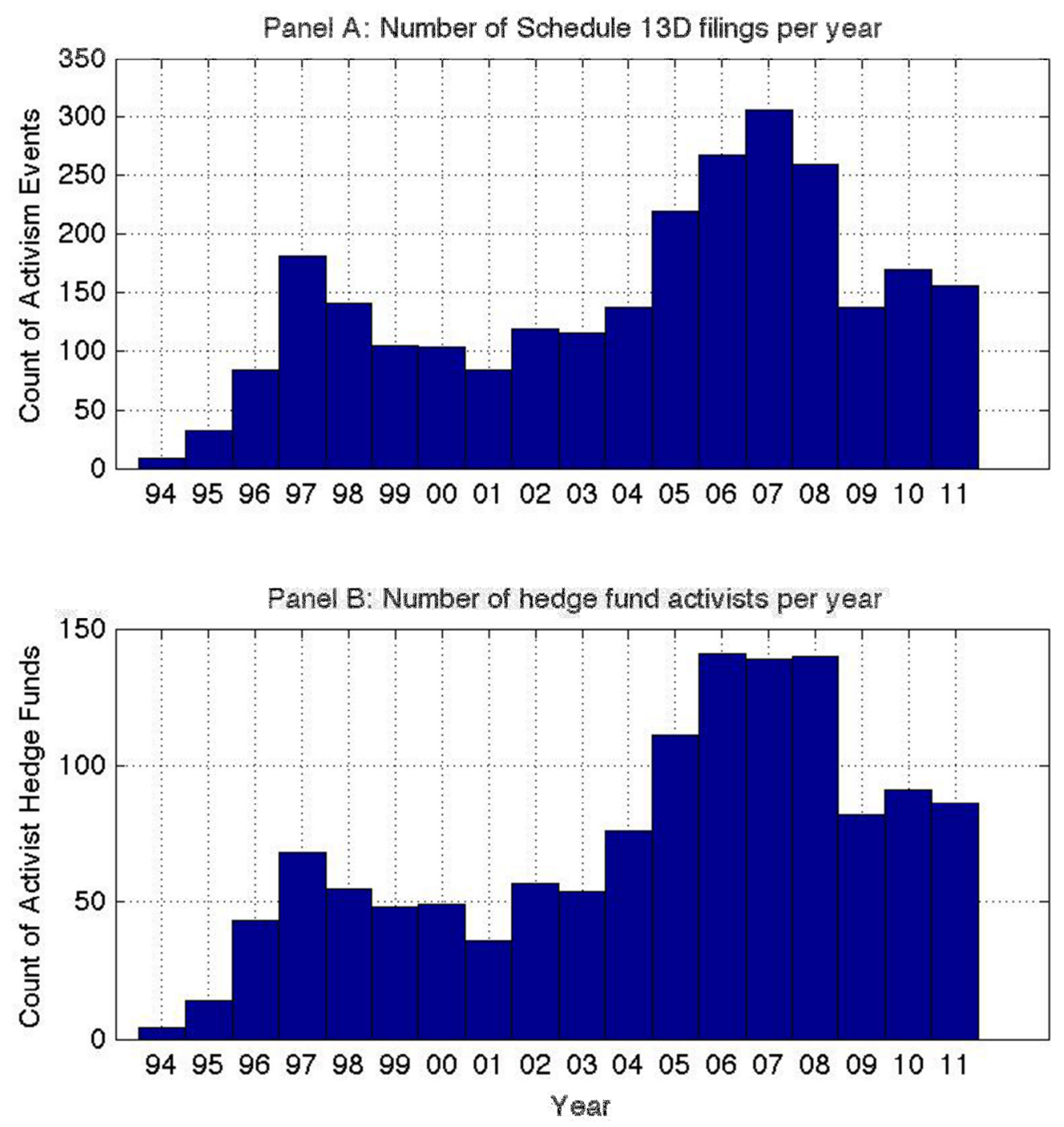
Figure 2: Short Run Average Abnormal Return

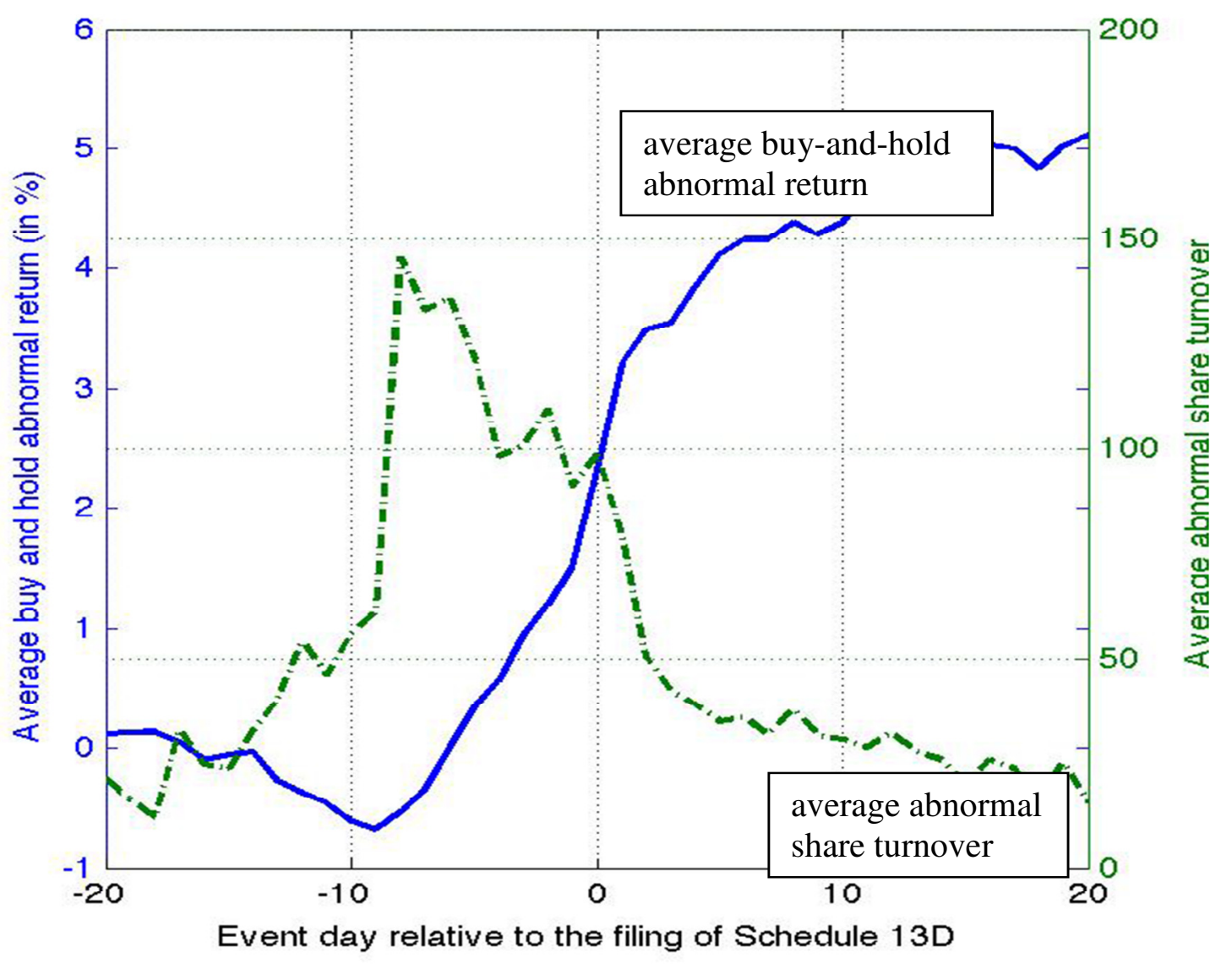


Figure 3: Short-run Market Reaction by Year

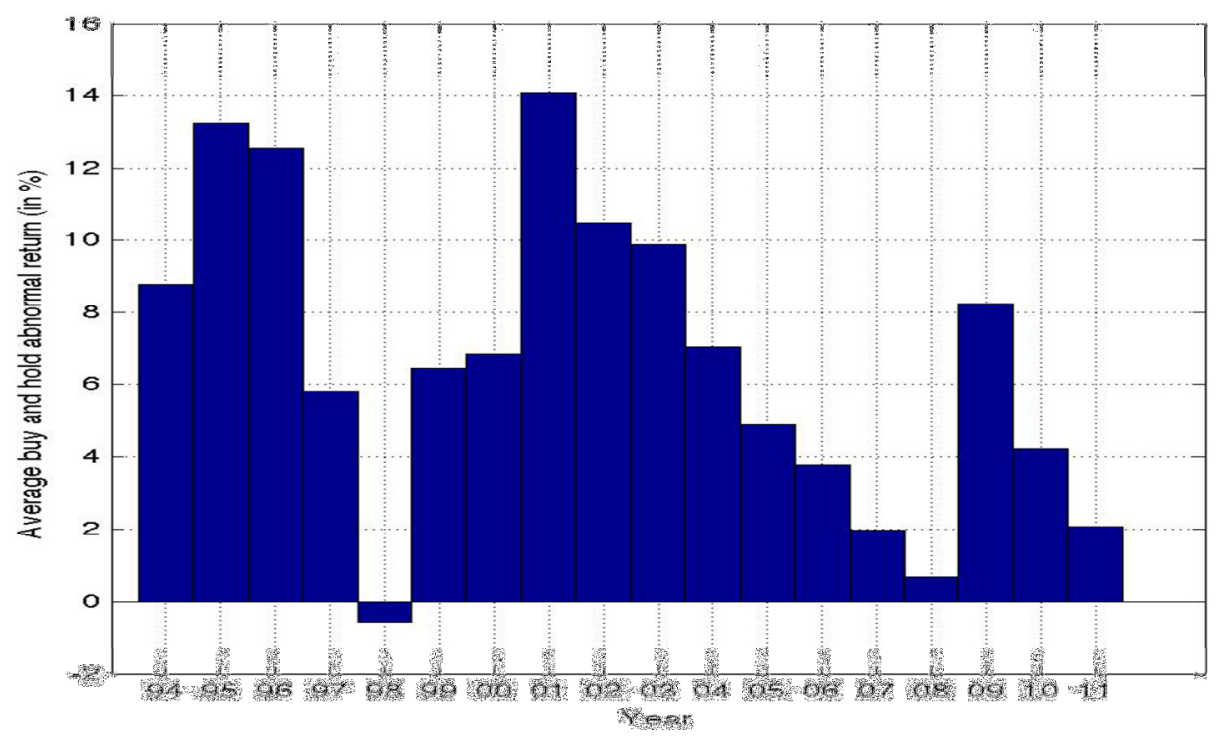

